\title{
The Relationship Between Inflation and Economic Growth of Bangladesh: An Empirical Analysis from 1961 to 2013
}

\author{
Md. Shakhaowat Hossin \\ Department of Finance and Banking, Begum Rokeya University, Rangpur, Bangladesh
}

\section{Email address:}

ms_shapon@yahoo.com

\section{To cite this article:}

Md. Shakhaowat Hossin. The Relationship Between Inflation and Economic Growth of Bangladesh: An Empirical Analysis from 1961 to 2013. International Journal of Economics, Finance and Management Sciences. Vol. 3, No. 5, 2015, pp. 426-434.

doi: 10.11648/j.ijefm.20150305.13

\begin{abstract}
The link between inflation and economic growth is one of the most important controversies in the economic literature. It is widely believed that moderate and stable inflation rates promote the development process of a country, and hence economic growth. Moderate inflation supplements return to savers, enhances investment, and therefore, accelerates economic growth of the country. This paper empirically explores the present relationship between inflation and economic growth in the context of Bangladesh. Using annual data set on real GDP and Gross Domestic Product Deflator (GDPD) for the period of 1961 to 2013, an assessment of empirical evidence has been acquired through the co-integration test, error correction models and Granger Causality test. The empirical evidence demonstrates that there exists a statistically significant long-run negative relationship between inflation and economic growth for the country as indicated by a statistically significant long-run negative relationship running from Gross Domestic Product Deflator (GDPD) to GDP. Again the empirical evidence demonstrates also that there exists a statistically significant long-run psoitive causality running from GDP to Gross Domestic Product Deflator (GDPD). In addition, economic growth affects inflation positively. But when increase in the rate of inflation goes beyond the threshold inflation level then inflation affects economic growth negatively. The paper discusses the important policy implications of the results.
\end{abstract}

Keywords: Inflation, Economic Growth, Bangladesh, Cointegration, Granger Causality

\section{Introduction}

One of the most fundamental objectives of macroeconomic policies is to sustain high economic growth together with low inflation. Specifically, the issue that whether inflation is necessary for economic growth or it is harmful generates a significant debate both theoretically and empirically. Some consensus exists, suggesting that macroeconomic stability, specifically defined as low inflation, is positively related to economic growth.

Macroeconomists, central bankers and policymakers have often emphasized the costs associated with high and variable inflation. Inflation imposes negative externalities on the economy when it interferes with an economy's efficiency. Examples of these inefficiencies are not hard to find, at least at the theoretical level.

Inflation can lead to uncertainty about the future profitability of investment projects (especially when high inflation is also associated with increased price variability).
This leads to more conservative investment strategies than would otherwise be the case, ultimately leading to lower levels of investment and economic growth. Inflation may also reduce a country's international competitiveness, by making its exports relatively more expensive, thus impacting on the balance of payments.

If inflation is indeed detrimental to economic activity and growth, then how low should inflation be? The answer to this question, obviously depends on the nature and structure of the economy, and will vary from country to country. Numerous studies with several theories have been carried out, which specifically aimed at examining the relationship between inflation and growth.

A series of studies found no conclusive empirical evidence for either a positive or a negative association between inflation and economic growth, notable among these studies are Wai, 1959; Bhatia, 1960; Dorrance, 1963, 1966, Johansen (1967).The second strand of the literature found a negative correlation between inflation and economic growth. Among these studies are Fisher (1993) De Gregorio (1993) Barro 
(1995, 1996); Brunno and Easterly (1995); Malla (1997); Faria and Carneiro (2001) Dewan \& Hussein (2001). While the third strand of the literature found a positive relationship between inflation and economic growth.

In this paper, we will examine several different economic theories and empirical studies to assess the relationship between inflation and economic growth. Ultimately, we will test whether a meaningful relationship between the two variables exists in Bangladesh. This paper is organized as follows; section one is the introduction while section two reviews the empirical literature on inflation and economic growth; section three discusses the model and methodology while section four provides data and empirical evidence and the final section which is section five provides the summary and conclusion of the study.

\section{Review of Related Literature}

The existence and nature of the link between inflation and economic growth have extensively been investigated in the economic literature. Most of this research work has been done internationally. We have critically reviewed some of these important empirical studies to develop objectives in the context of Bangladesh and, further, to analyze it to draw some important conclusions and policy recommendations.

${ }^{[1]}$ Barro (1995) examines the issue and finds a significant negative relationship between inflation and economic growth, considering variables like fertility rate, education, etc constant. The study contains a large sample data of more than 100 economies for the period 1960 to 1990 and to assess the effects of inflation on growth, a system of regression equations is used in which many other determinants of growth are held constant. This framework is based on an expanded view of the neoclassical growth model as stated by Barro and Sala-iMartin (1995). The study indicates that there exists a statistically significant negative relationship between inflation and economic growth. More specifically, an increase in the average annual inflation by 10 percentage points per year lowers the real GDP growth by 0.2 to 0.3 percentage points per year.

${ }^{[2]}$ Bruno and Easterly (1995) examined the determinants of economic growth using annual CPI inflation of 26countries which experienced inflation crises during the period between 1961 and 1992. In their empirical analysis, inflation rate of 40 percent and over is considered as the threshold level for an inflation crisis. They find inconsistent or somewhat inconclusive relationship between inflation and economic growth below this threshold level when countries with high inflation crises are excluded from the sample. In addition, the empirical analysis suggests that there exists a temporal negative relationship between inflation and economic growth beyond this threshold level. The robustness of the empirical results is examined by controlling for other factors such as shocks (e.g., terms of trade shocks, political crises, and wars). Finally, they found that countries recover their pre-crisis economic growth rates following successful reduction of high inflation and there is no permanent damage to economic growth due to discrete high inflation crises.

${ }^{[3]}$ Sarel (1996) explores the possibility of non-linear effects of inflation on economic growth and finds a significant structural break which occurs at annual average 8 percent inflation rate, in the function that relates economic growth to inflation. His results show that below that structural break, inflation has slightly positive effect on growth but after 8 percent inflation rate, it has powerful negative effect on growth These results have been found by using OLS technique after constructing a joint panel database by collecting annual information of 87 countries for the period 1970-1990.

Using the annual time series data for the period 1971-1995,

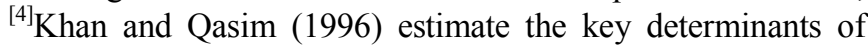
inflation in Pakistan. They disaggregate inflation into food and non-food inflation and suggest a strong role of money supply in accelerating inflation in Pakistan. Other factors causing inflation, investigated by the researchers, are currency devaluation, value addition in agriculture sector, support price of wheat, import prices and price of electricity.

${ }^{[5]}$ Malla (1997) conducted an empirical analysis using a small sample of Asian countries and countries belonging to the Organization for Economic Cooperation and Development (OECD) separately. After controlling for labor and capital inputs, the estimated results suggest that for the OECD countries there exists a statistically significant negative relationship between economic growth and inflation including its first difference. However, the relationship is not statistically significant for the developing countries of Asia. The crucial finding of this empirical analysis suggests that the crosscountry relationship between inflation and long-term economic growth experiences some fundamental problems like adjustment in country sample and the time period. Therefore, inconclusive relationship between inflation and economic growth can be drawn from comparing cross country timeseries regressions with different regions and time periods.

Short-run consequences of rapid disinflation are addressed by ${ }^{[6]}$ Ghosh and Phillips(1998), and find that starting from lower inflation rates; a rapid disinflation is associated with fall in GDP growth. They employ a large panel data set, covering IMF member countries for the period 1960-96. They find two important nonlinearities in the inflation growth relationship. At very low inflation rates (around 2-3 percent a year, or lower), inflation and growth are positively correlated. Otherwise, inflation and growth are negatively correlated, but the relationship is convex, so that the decline in growth associated with an increase from 10 percent to 20 percent inflation is much larger than that associated with moving from 40 percent to 50 percent inflation.

${ }^{[7]}$ Shitundu and Luvanda (2000) used the Least Trimmed Squares (LTS) method, as introduced by Rousseeuw and Leroy (1987), which detects regression outliers and produces robust regression, to examine the impact of inflation on economic growth in Tanzania. The empirical results obtained suggest that inflation has been harmful to economic growth in Tanzania.

${ }^{[8]}$ Nell (2000) examines the issue whether inflation is always harmful to growth or not? Considering the South African Economy's data for the period 1960-1999 and dividing it into 
four episodes, using Vector Auto Regressive (VAR) technique, his empirical results suggest that inflation within the singledigit zone may beneficial to growth, while inflation in the double digit zone appears to impose costs in terms of slower growth.

${ }^{[9]}$ Faria and Carneiro (2001) investigate the relationship between inflation and output for the economy of Brazil where permanent inflationary shock has been observed for the last many years. They use a bivariate vector auto-regression composed of output growth and the change in inflation in order to test the hypothesis that inflation has long run impact on output. They also use the data for the same period 1980-95 to estimate the short run relationship between inflation and real output. Their findings verify Sidrauski's super neutrality of money which can be defined as inflation has no real effect on output and productivity in the long-run. Their results suggest that inflation has real effects on output in the short run.

${ }^{[10]}$ Mallik and Chowdhury (2001) examined the short-run and long-run dynamics of the relationship between inflation and economic growth for four South Asian economies: Bangladesh, India, Pakistan, and Sri Lanka. Applying cointegration and error correction models to the annual data retrieved from the International Monetary Fund (IMF) International Financial Statistics (IFS), they found two motivating results. First, the relationship between inflation and economic growth is positive and statistically significant for all four countries. Second, the sensitivity of growth to changes in inflation rates is smaller than that of inflation to changes in growth rates. These results have important policy implications, that is, although moderate inflation promotes economic growth, faster economic growth absorbs into inflation by overheating the economy. Therefore, these four countries are on the turning point of inflation-economic growth relationship.

${ }^{[11]}$ Khan and Senhadji (2001) examine threshold effects of inflation on growth separately for industrial and developing countries. The data set covers 140 countries from both groups and non-linear least squares (NLLS) and conditional least squares methods are used. The empirical results verify the existence of a threshold beyond which inflation exerts a negative effect on growth. Significant thresholds at 1-3 percent and 11-12 percent inflation levels for industrialized and developing countries have been found. The view of low inflation for sustainable growth is strongly supported by this study.

Gillman, Harris and Matyas (2002) present an econometric model with the feature of the inflation rate reducing the return to capital, by taking two samples of OECD and APEC member countries over the years 1961-1997. Inflation rate is included as central variable and the theory is related with the concept of equilibrium along the balanced growth path that is implicitly includes transitional approaches to the balanced growth rate. The results, consistent with Khan and Senhadji (2000), show that the effective is negative and significant at low inflation rates for the OECD. When inflation rate going from $0-10$ percent range to a $0-5$ percent range, the negative co-efficient nearly doubles in magnitude and remains highly significant.

${ }^{[12]}$ Gokal and Hanif (2004) review several different economic theories to develop consensus on the inflation and growth relationship for the economy of Fiji. Their results show that a weak negative correlation exists between inflation and growth, while the change in output gap bears significant bearing. The causality between the two variables ran one-way from GDP growth to inflation.

${ }^{[13]}$ Sweidan (2004) examined whether the relationship between inflation and economic growth has a structural breakpoint effect or not for the Jordanian economy from the period between 1970 and 2003. He finds that this relation tends to be positive and significant below an inflation rate of 2-percent and the structural breakpoint effect occurs at an inflation rate equal to 2-percent. Beyond this threshold level inflation affects economic growth negatively.

${ }^{[14]}$ Ahmed and Mortaza (2005) empirically explored the relationship between inflation and economic growth in Bangladesh, using annual data set on real GDP and CPI for the period of 1980 to 2005, and the co-integration and error correction models. The empirical evidence demonstrates that there exists a statistically significant long-run negative relationship between inflation and economic growth for the country as indicated by a statistically significant long-run negative relationship between CPI and real GDP.

${ }^{[15]}$ Mubarik (2005) estimated the threshold level of inflation for Pakistan using an annual data set from the period between 1973 and 2000. He employed the Granger Causality test as an application of the threshold model and finally, the relevant sensitivity analysis of the model. His estimation of the threshold model suggests that an inflation rate beyond 9percent is detrimental for the economic growth of Pakistan. This in turn, suggests that inflation rate below the estimated level of 9-percent is favourable for the economic growth. Moreover, the sensitivity analysis performed for the robustness of the threshold model also confirms the same level of threshold inflation rate.

${ }^{[16]}$ Khan and Schimmelpfenning (2006) construct a simple inflation model taking data of economy of Pakistan for the period January 1998 to June 2005 and find that monetary factors determine inflation in Pakistan. They examine long run relationship between the CPI and private sector credit and their results show that there may be no trade-off between inflation and growth in the short run but it certainly exists in the medium and long run. Their estimated results suggest 5 percent inflation target for sustained economic growth and macroeconomic stability for the economy.

${ }^{[17]}$ Kemal (2006) finds that an increase in money supply over the long-run becomes the source of inflation and thus verifies the quantity theory of money. The results drawn by Khan and Schimmelpfenning (2006) have also been verified in the sense that the long-run excess money supply is the main responsible for inflation in Pakistan. This study contradicts with Hussain (2005) as its results imply that inflation in Pakistan is a monetary phenomenon.

${ }^{[18]}$ Saaed (2007) explored the relationship between inflation and economic growth in the context of Kuwait, using annual data set on real GDP and CPI for the period of 1985 to 2005. The estimated result of the relationship shows a long-run and 
strong inverse relationship between CPI and real GDP in Kuwait.

${ }^{[19]}$ Tan (2008) ascertained whether there is any trade-off between inflation and economic growth in the founding members of ASEAN namely Malaysia, Singapore, Thailand, the Philippines and Indonesia and Japan and South Korea. The purpose of the paper was met by integrating the Phillips curve framework with Okun's theory. Quarterly data of these countries spanning generally from 1991 through 2006/7 were mobilized for the purpose. The empirical results suggest that a trade-off albeit small exists between economic growth and inflation in Singapore, South Korea and Thailand after the 1997/98 Asian financial crisis years while none in the other countries. In the wake of these findings, one might somehow infer that monetary cooperation is sustainable amongst these sample countries.

${ }^{[20]}$ Erbaykal and Okuyan (2008) examined the relationship between the inflation and the economic growth in Turkey has been in the framework of data covering 1987:1-2006:2 periods The existence of the long term relationship between these two variables was examined using Bound Test developed by Pesaran et al. (2001), and the existence of a cointegration relationship between the two series was detected following the test result.

Whereas no statistically significant long term relationship was found with the formed ARDL models, a negative and statistically significant short term relationship has been found. The causality relationship between the two series was examined in the framework of the causality test developed by Toda Yamamoto (1995). Whereas no causality relationship was found from economic growth to inflation, a causality relationship was found from inflation to economic growth.

${ }^{[21]}$ Munir et al. (2009) analyze the non linear relationship between inflation level and economic growth rate for the period 1970-2005 in the economy of Malaysia. Using annual data and applying new endogenous threshold autoregressive (TAR) models proposed by Hansen (2000), they find an inflation threshold value existing for Malaysia and verify the view that the relationship between inflation rate and economic growth is nonlinear. The estimated threshold regression model suggests 3.89 percent as the structural break point of inflation above which inflation significantly hurts growth rate of real GDP. In addition, below the threshold level, there is statistical significant positive relationship between inflation rate and growth.

\section{Econometric Methodology}

Following the lead of Ahmed and Mortaza (2005) and Alfred (2007), the study employs two econometric models to achieve the empirical results. The first is, to examine the extent to which economic growth is related to inflation and vice versa, the theory of Johansen (1988) co-integration test and the associated Error Correction Model (ECM) is applied. With the help of this procedure it is possible to examine the short-run and long-run relationships between real GDP and Gross Domestic Product Deflator (GDPD) and the second is the application of the Granger causality test to determine the direction of causality between real GDP and Gross Domestic Product Deflator (GDPD).

\subsection{Model Specification}

The primary model showing the relationship between Economic Growth and Inflation is specified thus:

$$
\begin{gathered}
\text { GDP }=\mathrm{f}(\text { GDPD }) \\
G D P=\alpha_{0}+\alpha_{1} \text { GDPD }_{\mathrm{t}}+\varepsilon_{\mathrm{t}}
\end{gathered}
$$

GDP is Gross Domestic products as a proxy for economic growth

GDPD is the Gross Domestic Product Deflator used as a proxy for inflation

$\alpha_{0}$ is the constant term, ' $t$ ' is the time trend, and ' $\varepsilon$ ' is the random error term

\subsection{Data Description and Sources}

To capture the relationship between growth and Inflation, Economic growth was proxied by the GDP and the GDP deflator (GDPD) is used as a proxy for Inflation. The data covers the period from 1961 to 2013. All the variables are taken on annual basis from World Development Indicators (World Data Bank Online Version). All the variables are transformed in their natural logarithms in order to avoid the problems of heteroscedasticity and denoted as LGDP and LGDPD.

\subsection{Estimation Technique}

\subsubsection{Unit Root Test}

The first step involves testing the order of integration of the individual series under consideration. Researchers have developed several procedures for the test of order of integration. The most popular ones are Augmented DickeyFuller (ADF) test due to Dickey and Fuller (1979, 1981). Augmented Dickey-Fuller test relies on rejecting a null hypothesis of unit root (the series are non-stationary) in favour of the alternative hypotheses of stationarity. The tests are conducted with and without a deterministic trend $(t)$ for each of the series. The general form of ADF test is estimated by the following regression

$$
\begin{gathered}
\Delta y_{t}=\alpha_{0}+\alpha_{1} y_{t-1}+\sum_{i=1}^{n} \alpha \Delta y_{i}+e_{t} \\
\Delta y_{t}=\alpha_{0}+\alpha_{1} y_{t-1}+\sum_{n=1}^{n} \alpha_{1} \Delta y_{i}+\delta_{t}+e_{t}
\end{gathered}
$$

Where: $\mathrm{Y}$ is a time series, $\mathrm{t}$ is a linear time trend, $\Delta$ is the first difference operator, $\alpha_{0}$ is a constant, $n$ is the optimum number of lags in the dependent variable and $e$ is the random error term; the difference between equation (1) and(2) is that the first equation includes just drift. However, the second equation includes both drift and linear time trend $\mathrm{pp}$.

$$
\Delta y_{t}=\alpha_{0}+\alpha y_{t-1}+e_{t}
$$




\subsubsection{The Cointegration Test}

Once a unit root has been confirmed for a data series, the next step is to examine whether there exists a long-run equilibrium relationship among variables. The existence of long-run equilibrium (stationary) relationships among economic variables is referred to in the literature as cointegration which is very significant to avoid the risk of spurious regression. The basic idea behind cointegration is that if, in the long-run, two or more series move closely together, even though the series themselves are trended, the difference between them is constant. It is possible to regard these series as defining a long-run equilibrium relationship, as the difference between them is stationary (Hall and Henry, 1989). A lack of cointegration suggests that such variables have no long-run relationship: in principal they can wander arbitrarily far away from each other (Dickey et. al., 1991). We employ the VAR based on co-integration test using the methodology developed in Johansen $(1991,1995)$.

Johansen's methodology takes its starting point in the Vector Auto regression (VAR) of order P given by

$$
y_{t}=\mu+\Delta_{1} y_{t-1}+---+\Delta p y_{t-p}+\varepsilon_{t}
$$

Where $Y_{t}$ is an $n x 1$ vector of variables that are integrated of order commonly denoted (1) and $\varepsilon_{t}$ is an $n x 1$ vector of innovations.

This VAR can be rewritten as

$$
\Delta y_{t}=\mu+\eta_{y t-1}+\sum_{i-1}^{p-1} \tau_{i} \Delta y_{t-1}+\varepsilon_{t}
$$

Where

$$
\Pi=\sum_{i=1}^{p} A_{i-1} \text { and } \tau_{i}=-\sum_{j=i+1}^{n} A j
$$

To determine the number of co-integration vectors, Johansen (1988, 1989) and Johansen and Juselius (1990) suggested two statistic tests, viz., the trace test statistic, and the maximum eigenvalue test statistic.

Trace Test Statistic

The trace test statistic can be specified as:

$$
\tau_{\text {trace }}=-T \sum_{i=r+1}^{k} \log \left(1-\lambda_{i}\right)
$$

Where, $\lambda_{i}$ is the $i$ th largest eigenvalue of matrix $\Pi$ and $T$ is the number of observations. In the trace test, the null hypothesis assumes that the number of distinct cointegrating vector(s) be less than or equal to the number of cointegration relations (r).

Maximum Eigenvalue Test

The maximum eigenvalue test examines the null hypothesis of exactly $\mathrm{r}$ cointegrating relations against the alternative of $r+1$ cointegrating relations with the test statistic: $\tau_{\max }=-T \log \left(1-\lambda_{r+1}\right)$,

where $\lambda_{\mathrm{r}+1}$ isthe $(\mathrm{r}+1)^{\text {th }}$ largest squared eigenvalue.

In the trace test, the null hypothesis of $r=0$ is tested against the alternative of $r+1$ cointegrating vectors.
It is well known that Johansen's cointegration test is very sensitive to the choice of lag length. So first a VAR model is fitted to the time series data in order to find an appropriate lag structure. The Akaie Information Criterion (AIC), Schwarz Criterion (SC) and the Likelihood Ratio (LR) test are used to select the number of lags required in the cointegration test.

\subsubsection{Granger-Causality Test}

After the testing of the Cointegration relationship, we test for causality between Growth and Inflation in Bangladesh. If the two variables are co-integrated, an Error Correction term (ECT) is required to be included (Granger, 1988) in the following bivariate autoregression:

$$
\begin{gathered}
G D P_{t}=\alpha_{0}+\sum_{i=1}^{n} \alpha_{1 t} G D P_{t-1}+\sum_{i=1}^{m} \alpha_{2 t} G D P D_{t-1}+\delta_{1} E C T_{t-1}+\varepsilon_{1 t}(9) \\
G D P D_{t}=\beta_{0}+\sum_{i=1}^{m} \beta_{1 t} G D P_{t-1}+\sum_{i=1}^{n} \beta_{2 t} G D P D_{t-1}+\delta_{2} E C T_{t-1}+\varepsilon_{1 t}
\end{gathered}
$$

Where:

GDPt is Gross Domestic product

GDPD is the Gross Domestic Product Deflator used as a proxy for inflation

The term $\mathrm{ECT}_{\mathrm{t}-1}$ is the error correction term derived from the long-run cointegrating relationship in equation 3 . We note that the estimate $\delta_{1}$ and $\delta_{2}$ can be interpreted as the speed of adjustment. According to Johansen and Juselius (1987), the existence of cointegration implies the existence of the causality relation between the variables (Growth and Inflation) under the constraint $/ \delta_{1} /+/ \delta_{2} />0$. If cointegration relationship between the variables $\mathrm{GDP}_{\mathrm{t}}$ and $\mathrm{GDPD}_{\mathrm{t}}$ does not exist, the term ECT will be removed and the bivariate autoregression equation 9 and 10 becomes:

$$
\begin{gathered}
G D P_{t}=\alpha_{0}+\sum_{i=1}^{n} \alpha_{1 t} G D P_{t-1}+\sum_{i=1}^{m} \alpha_{2 t} G D P D_{t-1}+\varepsilon_{1 t} \\
G D P D_{t}=\beta_{0}+\sum_{i=1}^{m} \beta_{1 t} G D P_{t-1}+\sum_{i=1}^{n} \beta_{2 t} G D P D_{t-1}+\varepsilon_{1 t}
\end{gathered}
$$

Rejecting (accepting) $\mathrm{H}_{0} ; \alpha_{21}=\alpha_{22}=---------=\alpha_{2 \mathrm{~m}}$ in equation (9 and 10) or equation (11 and 12) suggests that Growth do (do not) Granger cause Inflation. On the other hand, rejecting (accepting) $\mathrm{H}_{0} ; \alpha_{11}=\alpha_{12}=$ suggest that Inflation do (do not) Granger Cause (have an effect) on Growth. These tests enable us to reveal the relationship of no causality, unidirectional causality of feedback causality between Money Supply and Inflation.

\section{Data and Empirical Results}

\subsection{Unit Root Test}

Unit Root Test involves testing for the stationarity of the individual variables (GDP and GDPD) using the Augmented Dickey Fuller (ADF) test to find the existence of unit root in each of the time series. The results of the ADF test are 
reported in Tables 4.1.1(Levels) and 4.1.2 (First Difference).

Table 4.1.1. ADF Stationarity test at Levels.

\begin{tabular}{|c|c|c|c|c|c|c|c|}
\hline \multirow{2}{*}{ Variables } & \multicolumn{6}{|l|}{ ADF } & \multirow{2}{*}{ Remark } \\
\hline & Intercep & & Interce & end & None & & \\
\hline LGDP & -1.931 & $\begin{array}{l}(-3.574)^{*} \\
(-2.923)^{* *}\end{array}$ & -5.339 & $\begin{array}{l}(-4.192)^{*} \\
(-3.520)^{* *}\end{array}$ & -0.659 & $\begin{array}{l}(-2.614)^{*} \\
(-1.947)^{* *}\end{array}$ & Non-Stationary \\
\hline LGDPD & -3.658 & $\begin{array}{l}(-3.976)^{*} \\
(-2.987)^{* *}\end{array}$ & -4.587 & $\begin{array}{l}(-4.165)^{*} \\
(-3.488)^{* *}\end{array}$ & -2.373 & $\begin{array}{l}(-2.521)^{*} \\
(-1.989)^{* *}\end{array}$ & Non-Stationary \\
\hline
\end{tabular}

Note: * and $* *$ denotes Significance at $1 \%$ \& 5\% level, respectively. Figures within parenthesis indicate critical values. Mackinnon (1991) critical value for rejection of hypothesis of unit root applied.

Source: Author's Estimation using Eviews 7.2.

Table 4.1.2. ADF Stationarity test at First Difference.

\begin{tabular}{|c|c|c|c|c|c|c|c|}
\hline \multirow{2}{*}{ Variables } & \multicolumn{6}{|l|}{ ADF } & \multirow{2}{*}{ Remark } \\
\hline & Intercep & & Intercep & end & None & & \\
\hline LGDP & -3.441 & $\begin{array}{l}(-3.592)^{*} \\
(-2.931)^{* *}\end{array}$ & -3.550 & $\begin{array}{l}(-4.186)^{*} \\
(-3.518)^{* *}\end{array}$ & -3.460 & $\begin{array}{l}(-2.619)^{*} \\
(-1.948)^{* *}\end{array}$ & $\mathrm{I}(1)$ \\
\hline LGDPD & -11.246 & $\begin{array}{l}(-3.565)^{*} \\
(-2.919)^{* *}\end{array}$ & -11.136 & $\begin{array}{l}(-4.148)^{*} \\
(-3.500)^{* *}\end{array}$ & -11.360 & $\begin{array}{l}(-2.611)^{*} \\
(-1.947)^{* *}\end{array}$ & $\mathrm{I}(1)$ \\
\hline
\end{tabular}

Note: * and $* *$ denotes Significance at $1 \%$ \& 5\% level, respectively. Figures within parenthesis indicate critical values. Mackinnon (1991) critical value for rejection of hypothesis of unit root applied.

Source: Author's Estimation using Eviews 7.2

To avoid the spurious regression first check the stationarity of the variables. For this purpose ADF Test has used. The table 4.1.1 and 4.1.2 shows result of ADF test with intercept, intercept \& trend and none (neither intercept nor trend in the model).

All the variables were not found stationary in levels. This can be seen by comparing the observed values (in absolute terms) of the ADF test statistics with the critical values (also in absolute terms) of the test statistics at the $1 \%, 5 \%$ and $10 \%$ level of significance. Result from table 4.1.1 provides strong evidence of non stationarity. Therefore, the null hypothesis is accepted and it is sufficient to conclude that there is a presence of unit root in the variables at levels.

By observing the above result, all the variables were differenced once and the ADF test was conducted on them as shown in table 4.1.2. The coefficients compared with the critical values $(1 \%, 5 \%$ and $10 \%)$ reveals that all the variables were stationary at first difference and on the basis of this, the null hypothesis of non-stationary is rejected and it is safe to conclude that the variables are stationary. This implies that the variables are integrated at order one, i.e. I (1).

\subsection{Cointegration Test Result and Analysis}

The result of the cointegration condition (that is the existence of a long term linear relation) is presented in Table 4.2.1 (Trace Statistics) and 4.2.2 (Maximum Eigenvalue) using methodology proposed by Johansen and Juselius (1990):

Table 4.2.1. Unrestricted Cointegration Rank Test (Trace).

\begin{tabular}{lllll}
\hline Hypothesized & & Trace & 0.05 & Prob.** \\
\hline No. of CE(s) & Eigenvalue & Statistic & Critical Value & 0.0000 \\
\hline None $*$ & 0.495766 & 40.79276 & 15.49471 & 0.0071 \\
At most $1 *$ & 0.137388 & 7.241716 & 3.841466 & \\
\hline
\end{tabular}

Trace test indicates 2 cointegrating eqn (s) at the 0.05 level

* denotes rejection of the hypothesis at the 0.05 level

**MacKinnon-Haug-Michelis (1999) p-values

Table 4.2.2. Unrestricted Cointegration Rank Test (Maximum Eigenvalue).

\begin{tabular}{lllll}
\hline Hypothesized & & Max-Eigen & $\mathbf{0 . 0 5}$ & Prob.** \\
\hline No. of CE(s) & Eigenvalue & Statistic & Critical Value & 0.0000 \\
\hline None ${ }^{*}$ & 0.495766 & 33.55104 & 14.26460 & 0.0071 \\
At most $1 *$ & 0.137388 & 7.241716 & 3.841466 & \\
\hline
\end{tabular}

Max-eigenvalue test indicates 2 cointegrating eqn (s) at the 0.05 level

* denotes rejection of the hypothesis at the 0.05 level

**MacKinnon-Haug-Michelis (1999) p-values

The results of Johansen test for cointegration reported in

Table 4.2.1 and Table 4.2.2 confirm the rejection of the null 
hypothesis of no co-integration between and GDP and GDPD In particular, the computed trace, the maximum eigen value statistics and their corresponding critical values indicate that the null hypothesis of no co-integration can be rejected under both of these tests at 5-percent levels of significance. Both maximum eigen value and trace tests indicate two cointegrating equation at 5-percent levels of significance. This implies a long-run relationship between inflation and economic growth in Bangladesh.

The second stage comprises of the estimation of the VECM. The VECM has several advantages: first, the VECM incorporates both the short-run and long-run effects assuming that the variables are co-integrated. The second one is that assuming co-integration; all the terms in the model are stationary so that standard regression techniques are valid (Harris, 1995). The estimated coefficients of the vector error correction term (long-run effects) and the lagged values of the two series (short-run effects) are presented in Table 4.2.3.

Table 4.2.3. Vector Error Correction Estimates.

\begin{tabular}{|c|c|c|}
\hline Error Correction: & D(GDP) & D(GDPD) \\
\hline \multirow[t]{3}{*}{ EC Term } & 0.419958 & -5.284361 \\
\hline & $(0.30791)$ & $(0.86340)$ \\
\hline & [ 1.36392$]$ & {$[-6.12042]$} \\
\hline \multirow[t]{3}{*}{$\mathrm{D}(\mathrm{GDP}(-1))$} & -0.952524 & 4.683828 \\
\hline & $(0.32792)$ & $(0.91953)$ \\
\hline & {$[-2.90471]$} & {$[5.09370]$} \\
\hline \multirow[t]{3}{*}{$\mathrm{D}(\mathrm{GDP}(-2))$} & -0.924230 & 3.347410 \\
\hline & $(0.27556)$ & $(0.77270)$ \\
\hline & {$[-3.35398]$} & [ 4.33207] \\
\hline \multirow[t]{3}{*}{$\mathrm{D}(\mathrm{GDP}(-3))$} & -0.432969 & 0.708075 \\
\hline & $(0.20823)$ & $(0.58390)$ \\
\hline & {$[-2.07928]$} & [ 1.21266$]$ \\
\hline \multirow[t]{3}{*}{$\mathrm{D}(\operatorname{GDPD}(-1))$} & 0.039674 & 0.222009 \\
\hline & $(0.05230)$ & $(0.14666)$ \\
\hline & {$[0.75856]$} & [ 1.51376$]$ \\
\hline \multirow[t]{3}{*}{$\mathrm{D}(\operatorname{GDPD}(-2))$} & -0.054263 & 0.277695 \\
\hline & $(0.04263)$ & $(0.11955)$ \\
\hline & {$[-1.27274]$} & [ 2.32280$]$ \\
\hline \multirow[t]{3}{*}{$\mathrm{D}(\operatorname{GDPD}(-3))$} & 0.007477 & -0.009641 \\
\hline & $(0.04088)$ & $(0.11463)$ \\
\hline & {$[0.18290]$} & {$[-0.08410]$} \\
\hline \multirow[t]{3}{*}{$\mathrm{C}$} & 0.058951 & -0.469285 \\
\hline & $(0.52624)$ & $(1.47563)$ \\
\hline & {$[0.11202]$} & {$[-0.31802]$} \\
\hline R-squared & 0.569805 & 0.747767 \\
\hline Adj. R-squared & 0.521275 & 0.704702 \\
\hline F-statistic & 7.572584 & 17.36397 \\
\hline Mean dependent & -0.102564 & 0.313604 \\
\hline S.D. dependent & 5.075864 & 18.89816 \\
\hline
\end{tabular}

* Standard errors in () \& t-statistics in [ ]

The empirical results show the existence of short-run and long-run relationships between GDPD and GDP in Bangladesh. This also implies short-run and long-run relationships between inflation and economic growth in the country. The estimated coefficients of the error correction term is significant at 5-percent level from GDPD to real GDP with appropriate (i.e., negative) sign. And the estimated coefficient of the error correction term is insignificant at 5percent level from GDP to GDPD with appropriate (i.e., positive) sign. That means that in the long-run if the two series are out of equilibrium, real GDP will adjust to reduce the equilibrium error and vice versa. The estimated results in the VECM also show that short-run changes in GDPD affect real GDP negatively and short-run changes in GDP affect GDPD positively.

\subsection{Granger Causality Test Analysis}

In many previous studies which examine causality, Granger Causality tests have been the most commonly used method. This is because it not only tests the correlation between two variables (as is tested by traditional approaches such as OLS regression), but also specifies the direction of causality. However, growth and inflation, as widely suggested by many economist scholars in the literature reviewed are known to relate inversely, in other words, the economy does not grow well in the midst of high inflation. In any case the following result shown in the tables below reveals the direction of causality between growth and inflation at lag three (3) and lag four (4). First a VAR model is fitted to the time series data in order to find an appropriate lag structure. The Akaie Information Criterion (AIC), Schwarz Criterion (SC) and the Likelihood Ratio (LR) test are used to select the number of lags required with author's estimation using Eviews 7.2.

Table 4.3.1. Pairwise Granger Causality Tests (lag 3).

\begin{tabular}{llll}
\hline Null Hypothesis: & Obs. & F-Statistic & Prob. \\
\hline LGDPD does not Granger Cause LGDP & 50 & 4.09876 & 0.0136 \\
LGDP does not Granger Cause LGDPD & & 16.9857 & 0.0000006 \\
\hline
\end{tabular}

Following the result in table 4.3.1, the null hypothesis that LGDPD does not Granger cause LGDP and that LGDP does not Granger Cause LGDPD are rejected and it is safe to conclude that there is a bi-directional causality between economic growth and inflation of Bangladesh at lag three (3).

Table 4.3.2. Pairwise Granger Causality Tests (lag 4).

\begin{tabular}{llll}
\hline Null Hypothesis: & Obs. & F-Statistic & Prob. \\
\hline LGDPD does not Granger Cause LGDP & 49 & 3.97536 & 0.0096 \\
LGDP does not Granger Cause LGDPD & & 13.2437 & 0.0000008 \\
\hline
\end{tabular}

In the result shown in table 4.3.2, the null hypothesis that LGDPD does not Granger cause LGDP and that LGDP does not Granger Cause LGDPD are rejected, further confirming a bi-directional causality exists between economic growth and inflation of Bangladesh at lag 4.

\section{Conclusion}

This paper empirically explores the present relationship between inflation and economic growth in the context of Bangladesh. The empirical evidence demonstrates that there exists a statistically significant long-run negative relationship between inflation and economic growth for the country as indicated by a statistically significant long-run negative relationship running from GDPD to GDP. 
Again the empirical evidence demonstrates also that there exists a statistically significant long-run positive causality running from GDP to GDPD. This result is more or less consistent with the predictions of Mallik and Chowdhury (2001). Particularly, they have mentioned that Bangladesh was already on the turning point (i.e., from positive to negative) of inflation-economic growth relationship in the late 1990s.

Besides the existence of cointegration existing between economic growth and inflation, further effort was made to check the causality relationship that exist between the two variables by employing the VAR-Granger causality approach at three lag periods as could be seen in Table 4.3.1 to Table 4.3.2. The first test was conducted using lag three (3) and in the result bi-directional causality was seen between economic growth and inflation of Bangladesh. Further test at lag four (4) was carried out and it supported the first by indicating a bi-directional causality between economic growth and inflation of Bangladesh.

In conclusion, the finding of this study is that economic growth affects inflation positively. But when increase in the rate of inflation goes beyond the threshold inflation level then inflation affects economic growth negatively.

Low or moderate inflation is an indicator of macroeconomic stability and creates an environment conducive for investment. Countries with low or moderate rates of inflation have higher growth rates over the long-term compared with countries with high inflation rates. However, low inflation does not constitute a sufficient condition for growth. To promote growth and keep inflation low, the government needs to control budget deficits. This can be achieved by switching public expenditure from consumption to investment, this may be a difficult policy to pursue, especially in a developing country with a multiparty democracy. It may be more realistic to choose 'tolerable' levels of inflation rate and achieve the maximum possible growth given that rate, by deficit-financed public investment.

\section{References}

[1] Barro, R. J. (1995). Inflation and Economic Growth. National Bureau of Economic Research (NBER) Working Paper No. 5326 (October).

[2] Bruno, M., and Easterly, W. (1995). Inflation Crises and Long-Run Growth, World Bank Policy Research Working Paper No. 1517.

[3] Sarel, M. (1996). Nonlinear Effects of Inflation on Economic Growth," IMF WP/95/56, Washington.

[4] Khan, A. H. and M. A. Qasim (1996).Inflation in Pakistan Revisited. The Pakistan Development Review, 35(4), 747-759.

[5] Malla, S. (1997). Inflation and Economic Growth: Evidence from a Growth Equation. Mimeo, Department of Economics, University of Hawai' I at Monoa, Honolulu. Available at www. hawaii. edu/ malla.

[6] Ghosh, A. and P. Steven (1998).Warning! Inflation May Be Harmful to Your Growth, IMF Staff Papers, 45(4), 672-710.

[7] Shitundu, J, L and Luvanda, E. G (2000). The Effect of
Inflation on Economic Growth in Tanzania. African Journal of Finance and Management, Vol. 9-1.

[8] Nell, K. S. (2000). Is Low Inflation a Precondition for Faster Growth? The Case of South Africa. Working Paper No. 7.

[9] Faria, J. R. and Carneiro, F. G. (2001). Does High Inflation Affect Growth in the Long and Short-run? Journal of Applied Economics, Vol. IV, No. 1, pp. 89-105.

[10] Mallik, G. and Chowdhury, A. (2001). Inflation and Economic Growth: Evidence from South Asian Countries," Asian Pacific Development Journal, Vol. 8, No.1., pp. 123-135.

[11] Khan, M. S. and Senhadji, A. S. (2001). Threshold Effects in the Relationship between Inflation and Growth, IMF Staff Papers, Vol. 48, No. 1.

[12] Gokal, V. and S. Hanif (2004).Relationship between Inflation and Economic Growth, Economics Department, Reserve Bank of Fiji, Suva, Fiji, Working Paper 2004/04.

[13] Sweidan, O. D. (2004). Does Inflation Harm Economic Growth in Jordan? An Econometric Analysis for the Period 1970-2000. International Journal of Applied Econometrics and Quantitative Studies, Vol. 1-2, pp. 41-66.

[14] Ahmed, S and M. G. Mortaza. (2005).Inflation and Economic Growth in Bangladesh: 1981-2005, Working Paper Series: WP 0604, Research Department, Bangladesh Bank, Dhaka, Bangladesh.

[15] Mubarik, Y. A. (2005). Inflation and Growth: An Estimate of the Threshold Level of Inflation in Pakistan," State Bank of Pakistan - Research Bulletin, Vol. 1, No. 1-2, pp. 35-44.

[16] Khan, M. S. and Schimmelpfenning, A. (2006). Inflation in Pakistan. The Pakistan Development Review, 45(2), 185-202.

[17] Kemal, M. A. (2006).Is Inflation in Pakistan a Monetary Phenomenon? The Pakistan Development Review, 45(2), 213220 .

[18] Saaed, A. (2007). Inflation and Economic Growth in Kuwait: 1985-2005 Evidence from Cointegration and Error Correction Model' Applied Econometrics and International Development Vol. 7-1.

[19] Tan, Eu Chye (2008). Inflation and Economic Growth in ASEAN-5, Japan and South Korea. In: $11^{\text {th }}$ International Convention of the East Asian Economic Association, 15-16 November 2008, Manila. (Unpublished).

[20] Erbaykal, E. and Okuyan, H. A. (2008). Does Inflation Depress Economic Growth? Evidence from Turkey. International Research Journal of Finance and Economics, Issue 17, no. 1450-2887.

[21] Munir, Q. et al. (2009). Inflation and Economic Growth in Malaysia: A Threshold Regression Approach, ASEAN Economic Bulletin, 26(2), 180-193.

[22] Culver, E. S. and Papell, H. D. (1997). Pitfalls and Opportunities: What Macroeconomics Should Know about Unit Roots, in O. J. Blanchard and S. Fischer, eds., NBER Macroeconomics Annual 1991, Cambridge: MIT Press.

[23] Tobin, J. (1965)"Money and Economic Growth," Econometrica, 33, pp. 671-684.

[24] De Gregorio, José. (1993). Effects of Inflation on Economic Growth: Lessons from Latin America. European Economic Review, Vol. 36 (April), pp. 417-25. 
[25] Dickey, D. A. and Fuller, W. A. (1981). Likelihood Ratio Statistics for Autoregressive Time Series with a Unit Root. Econometrica, Vol. 49 (, pp. 1057-1072.

[26] Engle, R. F. and Yoo, B. S. (1991). Co-integrated Economic Time Series: An Overview with New Results in R. F. Engle and C. W. J. Granger, eds., Long-Run Economic Relationships, Oxford: Oxford University Press, pp. 237-266.

[27] Johansen, S. and K. Juselius. (1990). Maximum Likelihood Estimation and Inference on Co-integration with the Application to the Demand for Money. Oxford Bulletin of Economics and Statistics, Vol. 52, pp. 169-210.
[28] Kwiatkowski, D., Phillips, P., Schmidt, P., and Shin, Y. (1992). Testing the Null Hypothesis of Stationary against the Alternative of a Unit Root. Journal of Econometrics, Vol. 54, pp. 159-178.

[29] MacKinnon, J. (1991). Critical Values for Co-integration Tests, In R. F. Engel and C. W. J. Granger, eds., Long Run Economic Relationships: Readings in Co-integration, Oxford: Oxford University Press.

[30] Engle, R. F. and Granger, C. W. J. (1987). Co-integration and Error Correction: Representation, Estimation and Testing. Econometrica, Vol. 55), pp. 1-87. 